\title{
Lactococcus lactis glyceraldehyde-3-phosphate dehydrogenase gene, gap: further evidence for strongly biased codon usage in glycolytic pathway genes
}

\author{
Michael R. Cancilla, ${ }^{1}+$ Alan J. Hillier ${ }^{2}$ and Barrie E. Davidson ${ }^{1}$ \\ Author for correspondence: Barrie E. Davidson. Tel: +613344 5912. Fax: +6133477730. \\ e-mail: davidson@biochemistry.unimelb.edu.au
}

\begin{abstract}
1 Russell Grimwade School of Biochemistry, University of Melbourne, Parkville, Victoria 3052, Australia

2 Commonwealth Scientific and Industrial Research Organization, Division of Food Science and Technology, Melbourne Laboratory, Highett, Victoria 3190, Australia
\end{abstract}

The gene gap, encoding glyceraldehyde-3-phosphate dehydrogenase (EC 1.2.1.12), was isolated from a genomic library of Lactococcus lactis LM0230 DNA. Plasmids containing the $L$. lactis gene were able to complement a gap mutant of Escherichia coli. The nucleotide sequence of gap predicted a polypeptide chain of 337 amino acids for the enzyme and a subunit molecular mass of 36043 . The codon usage in gap and four other glycolytic genes from $L$. lactis showed a high degree of bias, when compared with 84 other chromosomal genes. Northern blot analysis of total $L$. lactis RNA showed that gap hybridized strongly with a $1.3 \mathrm{~kb}$ transcript. The 5 ' end of the transcript was determined by primer extension analysis to be a $\mathrm{C}$ located 35 bp upstream from the gap start codon. These transcript analyses, and the orientation of the open reading frames in the DNA flanking gap, indicated that in L. lactis gap is expressed on a monocistronic transcript. Nucleotide sequencing indicated that the DNA adjacent to gap did not encode other glycolytic pathway enzymes. The DNA sequence flanking gap contained two open reading frames (ORF156 and ORF211) of unknown function. The $3^{\prime}$ end of a clpA homologue was identified in the sequence upstream of ORF156. The location of gap on the $L$. lactis DL11 chromosome map was determined to be between map coordinates 0.530 and 0.660 .

Keywords: Lactococcus lactis, glyceraldehyde-3-phosphate dehydrogenase, transcript analysis, Clp family, chromosome mapping

\section{INTRODUCTION}

Lactococcus lactis is a Gram-positive bacterium that is used extensively for making cheese. Lactose catabolism to lactic acid provides most of the energy needs of this bacterium. The production of lactic acid requires the interplay of three metabolic pathways: the phosphoenolpyruvate:phosphotransferase system, the tagatose-6phosphate pathway, and the Embden-Meyerhoff-Parnas (glycolytic) pathway (Thompson, 1987). The glycolytic pathway is responsible for the net production of two ATP molecules per molecule of hexose consumed. There is

†Present address: The Murdoch Institute, Royal Children's Hospital, Flemington Road, Parkville, Victoria 3052, Australia.

The GenBank accession number for the nucleotide sequence reported in this paper is $L 36907$. limited information regarding the structure, organization and expression of genes involved in the central metabolism of carbohydrates in L. lactis. Four of the L. lactis genes involved in glycolysis have been cloned and characterized. These are $p f k, p y k, l d h$ and $t p i$, which encode phosphofructokinase (EC 2.7.1.11), pyruvate kinase (EC 2.7.1.40), lactate dehydrogenase (EC 1.1.1.27) and triosephosphate isomerase (EC 5.3.1.1), respectively (Llanos et al., 1992, 1993; Griffin et al., 1992; Cancilla et al., 1995). Transcriptional analyses demonstrated that $p f k$, $p y k$ and $l d h$ are organized in an operon (designated $l a s$ ) and expressed as a tricistronic mRNA, whereas tpi was found to be monocistronic. These four glycolytic genes were found to exhibit a strong bias in their codon usage (Cancilla et al., 1995).

Glyceraldehyde-3-phosphate dehydrogenase (EC 1.2.1.12) catalyses the reversible oxidative phosphoryl- 
Table 1. Bacterial strains, plasmids and bacteriophage used in this study

\begin{tabular}{|c|c|c|}
\hline $\begin{array}{l}\text { Strain, } \\
\text { plasmid or } \\
\text { bacteriophage }\end{array}$ & Characteristics* & $\begin{array}{l}\text { Source or } \\
\text { reference }\end{array}$ \\
\hline \multicolumn{3}{|l|}{ Strains } \\
\hline \multicolumn{3}{|l|}{ L. lactis } \\
\hline LM0230 & $\begin{array}{l}\text { Plasmid-cured derivative of } L \text {. lactis subsp. cremoris } \mathrm{C} 2 \\
\text { (formerly described as } L \text {. lactis subsp. lactis } \mathrm{C} 2 \text { ) }\end{array}$ & $\begin{array}{l}\text { Efstathiou \& McKay } \\
\text { (1977); Salama et al. } \\
\text { (1991) }\end{array}$ \\
\hline DL11 & $\mathrm{Prt}^{-}$derivative of L. lactis subsp. lactis ATCC 11454 & Tulloch et al. (1991) \\
\hline \multicolumn{3}{|c|}{ ( } \\
\hline JM107 & $\begin{array}{l}\text { end } A 1 \text { gyr } A 96 \text { thi-1 bsdR } 17 \text { sup E44 relA1 } \Delta(\text { lac-pro } A B)\left(\mathrm{F}^{\prime}\right. \\
\left.\operatorname{traD} 36 \text { pro } A B \text { lac }{ }^{\mathrm{q}} Z \Delta \mathrm{M} 15\right)\end{array}$ & $\begin{array}{l}\text { Yanisch-Perron et al. } \\
\text { (1985) }\end{array}$ \\
\hline SURE & $\begin{array}{l}\mathrm{e} 14^{-}(m c r A) \Delta(m c r C B-b s d S M R-m r r) 171 \text { sbcC recB recJ } \\
\text { umuC::Tn5 }\left(\mathrm{Km}^{\mathrm{r}}\right) \text { worC supE44 lac gyr A96 relA1 thi-1 } \\
\text { end } A 1\left[\mathrm{~F}^{\prime} \text { pro } A B \text { lac } \mathrm{I}^{\mathrm{q}} \mathrm{Z} \Delta \mathrm{M} 15 \operatorname{Tn} 10\left(\mathrm{Tc}^{\mathrm{r}}\right)\right]\end{array}$ & Stratagene \\
\hline DF221 & $g a p^{-}$amber mutant derived from E. coli $\mathrm{K}-10$ & $\begin{array}{l}\text { Hillman \& Fraenkal } \\
\text { (1975) }\end{array}$ \\
\hline \multicolumn{3}{|l|}{ Plasmids } \\
\hline pGEM3zf $(+)$ & $A p^{r} ; \Delta l a c Z, 3 \cdot 2 \mathrm{kbp}$ cloning vector & Promega \\
\hline pJDC9 & $\mathrm{Em}^{\mathrm{r}} ; \Delta$ lac $Z, 6.85 \mathrm{kbp}$ cloning vector & $\begin{array}{l}\text { Chen \& Morrison } \\
(1988)\end{array}$ \\
\hline pMU5520 & $\begin{array}{l}\text { Ap }{ }^{r} \text {; pGEM } 3 z f(+) \text { with } 200 \text { bp fragment of gap prepared } \\
\text { by PCR amplification of L. lactis LM0230 DNA }\end{array}$ & This study \\
\hline pMU5521 & $\begin{array}{l}\mathrm{Em}^{\mathrm{r}} \text {; pJDC9 with } 1.9 \mathrm{kbp} \text { EcoRI fragment containing part } \\
\text { of L. lactis gap }\end{array}$ & This study \\
\hline pMU5522 & $\begin{array}{l}\mathrm{Em}^{\mathrm{r}} ; \mathrm{pJDC} \text { with } 2.0 \mathrm{kbp} \text { HindIII fragment containing } \\
\text { part of L. lactis gap }\end{array}$ & This study \\
\hline pMU5523 & $\begin{array}{l}\mathrm{Em}^{\mathrm{r}} ; \text { pJDC9 with } 3.1 \mathrm{kbp} N r u \mathrm{I} \text { fragment containing } L \text {. } \\
\text { lactis gap }\end{array}$ & This study \\
\hline pMU5524 & $\begin{array}{l}\mathrm{Em}^{\mathrm{r}} ; \mathrm{pJDC} 9 \text { with } 3 \cdot 1 \mathrm{kbp} N \mathrm{ruI} \text { fragment in reverse } \\
\text { orientation to pMU5523 }\end{array}$ & This study \\
\hline \multicolumn{3}{|l|}{ Bacteriophage } \\
\hline$\lambda 70$ & $\begin{array}{l}\lambda \text { GEM11 with a } 13.5 \mathrm{kbp} \text { partial Sau3AI fragment } \\
\text { containing gap from } L \text {. lactis LM0230 in the XboII site }\end{array}$ & This study \\
\hline
\end{tabular}

${ }^{*} \mathrm{Km}^{\mathrm{r}}, \mathrm{Tc}^{\mathrm{r}}, \mathrm{Ap}^{\mathrm{r}}$ and $\mathrm{Em}^{\mathrm{r}}$ indicate resistance conferred to kanamycin, tetracycline, ampicillin and erythromycin, respectively.

ation of glyceraldehyde 3-phosphate to produce 1,3bisphosphoglycerate, using $\mathrm{NAD}^{+}$as a coenzyme (Harris \& Waters, 1976). This enzyme, in conjunction with 3phosphoglycerate kinase (EC 2.7.2.3), forms a central link between ATP production and $\mathrm{NAD}^{+}$reduction, and therefore has a key role in glycolysis. This has been underscored by metabolic studies which showed that the decrease in glycolytic activity observed after starved $L$. lactis cells were provided with an energy source was primarily due to diminished glyceraldehyde-3-phosphate dehydrogenase activity (Poolman et al., 1987). Since the publication of the amino acid sequence of lobster glyceraldehyde-3-phosphate dehydrogenase (Davidson et al., 1967), the primary structures and predicted sequences of glyceraldehyde-3-phosphate dehydrogenases from many organisms have been reported, and all of the sequences share considerable similarity (Fothergill-Gilmore \& Michels, 1993). Antisera directed against the glyceralde- hyde-3-phosphate dehydrogenases of Streptococcus faecalis, Pediococcus damnosus and Lactobacillus acidophilus were used to demonstrate the relationships between five genera of Gram-positive lactic acid bacteria (London \& Chace, 1983).

Given the key role of glyceraldehyde-3-phosphate dehydrogenase in production of lactic acid by glycolysis, studies were performed to isolate and characterize gap from $L$. lactis. In this report we describe the construction of a molecular probe, the cloning and sequencing of gap, and its transcriptional organization. Codon usage in gap and other glycolytic genes from $L$. lactis is discussed with respect to codon preference in $L$. lactis.

\section{METHODS}

Bacterial strains, plasmids, bacteriophage, and culture conditions. The bacterial strains, plasmids and bacteriophage used 
in this study are listed in Table 1. L. lactis and Escherichia coli were grown as described previously (Cancilla et al., 1995) except that E. coli DF221 was maintained on Fraenkal II medium (Hillman \& Fraenkal, 1975) and grown on 56/GLC (halfstrength minimal medium 56 of Monod et al., 1951, supplemented with $0.4 \%, \mathrm{w} / \mathrm{v}$, glucose) in complementation experiments.

DNA and RNA techniques. Methods used for plasmid and bacteriophage DNA purification, isolation of $L$. lactis genomic DNA, oligonucleotide synthesis, nucleotide sequencing and analysis, restriction endonuclease digestions, Southern and Northern hybridizations, and primer extensions were as described previously (Cancilla et al., 1995).

Amplification of a molecular probe for gap. Degenerate oligonucleotides of the following sequences were used as primers in the polymerase chain reaction (PCR): GAPDH-1, 5'-TG(TC)AC(TCAG)AC(TCAG)AA(TC)TG(TC)(TC)T(TCAG)GC(TCAG)CC-3' ; and GAPDH-2, 5'-AC(AT)GC(TC)TT(AT)GC(AT)GC(AT)CC(ATC)GT-3'. GAPDH-1 and GAPDH-2 encode highly-conserved amino acid sequences found in most bacterial glyceraldehyde-3-phosphate dehydrogenases (Fothergill-Gilmore \& Michels, 1993). GAPDH-1 encodes CTTNCLAP (approximately residues 151 to 158 ), and GAPDH-2 encodes TGAAKAV (approximately residues 209 to 215 ) on the antisense strand. The PCR mix (50 $\mu \mathrm{l}$ final volume) consisted of template DNA (25 ng), degenerate oligonucleotide primers ( $250 \mathrm{ng}$ of each), deoxynucleoside triphosphates $(200 \mu \mathrm{M}$ each), $1 \times$ Taq DNA polymerase buffer (Boehringer Mannheim), and $1 \mathrm{U}$ Taq DNA polymerase (Boehringer). The reaction was carried out in a thermal sequencer (model FTS-1C, Corbett Research) as follows: $95^{\circ} \mathrm{C}$ for $3 \mathrm{~min}$, and then 35 cycles of $45^{\circ} \mathrm{C}$ for $1 \mathrm{~min}, 72^{\circ} \mathrm{C}$ for $1.5 \mathrm{~min}$, and $90^{\circ} \mathrm{C}$ for $0.5 \mathrm{~min}$.

SDSPAGE. SDS-PAGE of crude cell extracts was carried out using the Phast system (Pharmacia LKB) according to the procedures recommended by the manufacturer. The size of the glyceraldehyde-3-phosphate dehydrogenase subunit was determined by comparison of its electrophoretic mobility with those of a set of molecular mass standards of 14 to $94 \mathrm{kDa}$ (Pharmacia LKB).

\section{RESULTS}

\section{Molecular cloning of gap, the gene encoding glyceraldehyde-3-phosphate dehydrogenase}

Alignment of the known amino acid sequences of glyceraldehyde-3-phosphate dehydrogenases from different organisms revealed a number of highly conserved regions (Fothergill-Gilmore \& Michels, 1993). The sequences of two of these regions were used to design degenerate oligonucleotide primers for the production of a specific probe for gap by PCR. When PCR was carried out with these primers (designated GAPDH-1 and GAPDH-2; see Methods) and L. lactis LM0230 DNA template, a single PCR product of $200 \mathrm{bp}$, the size expected from the amino acid sequence alignments, was obtained. The $200 \mathrm{bp}$ PCR product was cloned (pMU5520) and its nucleotide sequence was determined. The sequence contained an open reading frame (ORF) with a predicted amino acid sequence exhibiting between 45 and $63 \%$ identity with part of the sequences of glyceraldehyde-3-phosphate dehydrogenases from other bacteria. The $200 \mathrm{bp}$ PCR

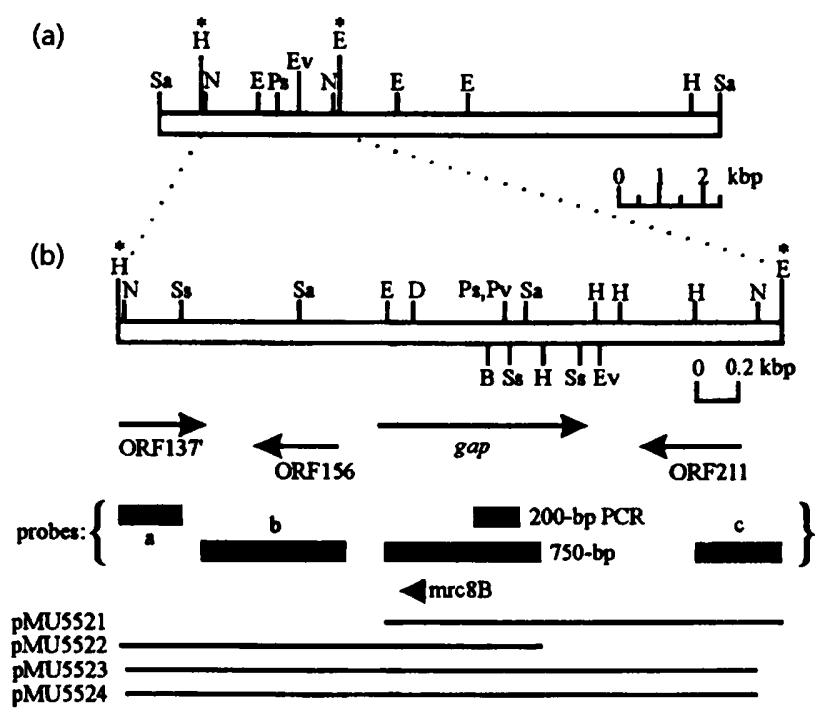

Fig. 1. (a) Restriction map of the $L$. lactis DNA in $\lambda 70$. (b) Restriction map of gap and flanking DNA. Only the relevant sites are shown for Sau3AI (Sa), HindIII (H), Nrul (N), EcoRI (E), Sspl (Ss), Dral (D), BstEll (B), Pstl (Ps), Pvull (Pv) and EcoRV (Ev). The solid lines beneath the map in (b) indicate DNA fragments described in Table 1; the solid boxes indicate the positions of the DNA fragments used as hybridization probes. The relative positions (and orientations) of gap, and other ORFs, are indicated by arrows. The location of oligonucleotide mrc8B used in primer extension analysis is indicated.

product was used as a specific probe for gap to screen a $\lambda$ GEM11 genomic library of L. lactis LM0230 (Llanos et al., 1992). Seven out of the 780 clones in the library hybridized strongly with the probe. DNA was isolated from these clones, digested with EcoRI, and Southernblot analyses were carried out on the digests to identify a clone containing the entire gap gene (data not shown). This clone, designated $\lambda 70$, was used to construct a restriction map for the $L$. lactis DNA surrounding gap (Fig. 1a).

\section{Nucleotide sequence of gap and flanking DNA}

Restriction fragments containing gap and its flanking DNA were subcloned from $\lambda 70$ into pJDC9, and their nucleotide sequences were determined. The $3244 \mathrm{bp}$ nucleotide sequence obtained is shown in Fig. 2. The largest ORF in this sequence (354 codons, bp 1199 to 2260) contained the nucleotide sequence determined previously for the $200 \mathrm{bp}$ gap probe. Using the first ATG in this ORF as the translation initiation codon, the deduced amino acid sequence shared between 45 and $68 \%$ identity with the sequences of glyceraldehyde-3-phosphate dehydrogenases from other bacteria (Fig. 3). Curiously, the regions used to design the degenerate oligonucleotides used in the PCR were not completely conserved in the glyceraldehyde-3-phosphate dehydrogenase of L. lactis (positions 156 and 212; Fig. 3). This sequence homology provided strong evidence that the 354 codon ORF was the gene gap, encoding glycer- 


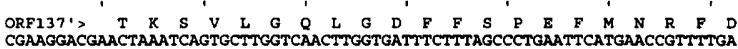

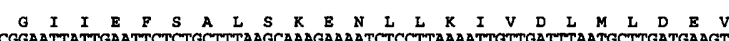

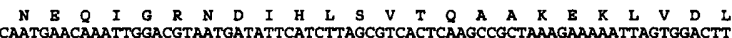

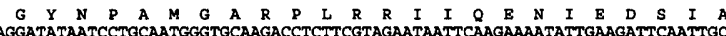
D E F Y I I E H P P E

$\underset{\text { TAATCAAACCCAAGAAACAGCAGAAACTACTGACGAAGAAGTTCCTGCTGAATAAAAAGTTTTGTCAGTAA }}{\mathbb{N}}$ ataGTATTAGTGACAGAAARACAAGAATAATGAAACAATGAAAAAATTGCTGACGAGATTAACGTCAGCAAT $\overline{\text { TTTTTCTATTCACAATGAACTGCCAGAAATTCTGTCAGTAAATTTTTCAATCCATTTCGTCAATCCACTCAT }}$ CAAGATAGCCGAGATTGTAATTATATTGGGTTTCGTCAGCAACTTGGGCTAGCGATACATTTGACAAGGTTC

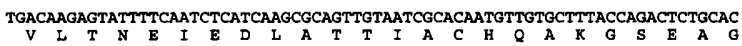
CAATAAAATTTTGTAAGAGTCCTTGACTTTGAAAAATTCGTCCACGGCCCTCAATGGCCAAGAAGACATCAT I $F$ N Q Q L L G Q Q S Q F I I R G R G E I A L F V D

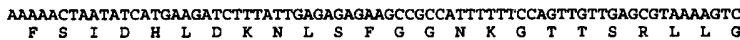

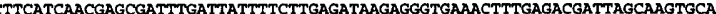

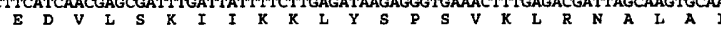
TGGATGACATCGTCCGATTTTCAGGAAGTCTTGCCAAAATAAGTAAAACGTAAACAGATTGTTCCCAACCAG ATGATAATTTCATAATAAAAACTCCTTAAACATTTTTAGTAAAAAAAATTGACACTAAATAAAAAAAGTAGT $S$ L K M CORF156

ATCATTTATATTAGAGATAAGAGATGTCTCCARTAACTATAAATTCATTATTTATATTATACCACAGCAGTT

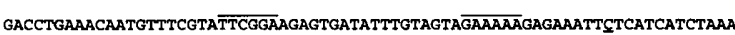
TAAAAAAACGGAGGACTACATCATGGTAGTTAAAGTTGGTATTAACGGTTTTGGTCGTATTGGACGTTTGGC $\underset{\text { ATTACGTCGAATTCAAGAAGTCGAAGGAGTTGAAGTAGCGCACATCAATGATTTGACAGACCCAGCAATGCT }}{\mathbf{L}} \underset{\mathbf{R}}{\mathbf{R}} \mathbf{R}$

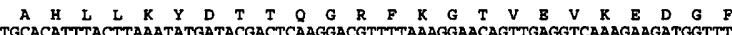
$\begin{array}{lllllllllllllllllllllll}D & V & N & G & K & F & V & K & V & T & A & E & R & N & P & E & D & I & Q & W & A & D & S\end{array}$ $\underset{\text { TGTGGAAATTGTTCTTGAAGCGACAGGTTTCTTTGCGACTAAAGAAAAAGCTGAAAAACATTTGCATCCTOG }}{\mathbf{V}} \mathbf{E}$ I V V L E

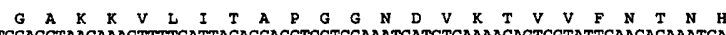

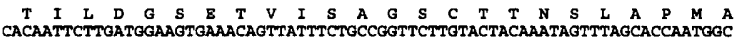

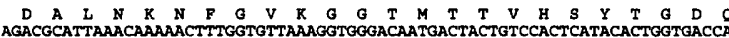

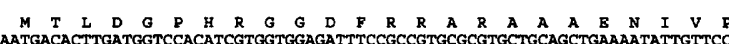
$\underset{\text { AGCATCAAGTGGAGCGGCTAAAGCAATTGGTCTTGTTTTGCCTGAGCTTTCTGGTTTGATGAAAGGACATGC }}{A} \mathbf{S}$

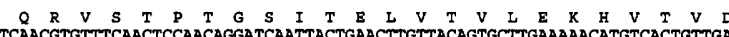
$\underset{\text { TGAAATCAACGAAGCAATGAAAGCTGCTGCTGATGAAAGCTTTGGCTATAATGTTGATGAAATTGTGTCATC }}{\mathbf{E}}$ I $\underset{\text { TGACATTATCGGCATGGCTTACGGTTCACTCTTTGATGCGACATTGACTGAAGTGACAGACTTAAAAGACGG }}{\mathbf{D}}$

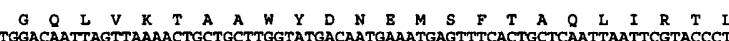

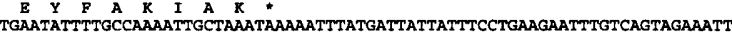
GCTGACAAAAGCTTTGGGATATCCGTAAACTGCTAAGGCAAGTAAGGCTAATCTAAGATTATTTAATGTGAA CACAGTAAACGTTAAAGCTGTGGATAAAAAAATTACTGACAGAAGCTTGCCAGTAATTTTAACTTTATTTTG TATTTTTAATGACAAATTCATTAGTGAATTTGCTGATTATTTAACAATAATCATGCCATCTTTAATTTCCC AGGGTCATTCATATTGATGTGGTCATAGAACATGACACCATTAGTGTGGTCAATTTCGTGTTGACACAAAT GGCTGGAAAATCTTTTAAGCGAATTTTTTTCTTTTCGCCTTCTTTGTTGTAGTATTCCACAGTTACACGAGC ATGACGAACGACGTAACCTGGAACTTCACGOTCAACAGAAAGACAACCTTCGCCACCTTCAACGGCCGCATC

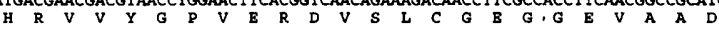
TTGTACAGAATGGCTAACCACTTTTGCATTATACATGATTTCACGCATTTTGTAAGCTTCTTTAGGTGGAT TTCATTTCCTTCTTCATCGACTTCAGGTTCATTAGGAATCAAAACGGCAATGACTTTTTTGAGCAAACCAAG

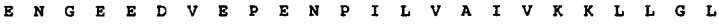

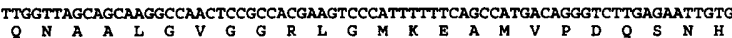
CAAGAATTGCAACATTTTTTCCCCTAAGATGATGTCTTCATCTGATAATGGCAAGGTCACATCATTTGCGAC TTCACGTAAGGTTGGGTATCCTTCACGAATAATATCOTCCATGCTAATCATGTGACTTGCTTTAATTAAATT TGCTTGAATTTCATCGCGATTCATTATTAATAAAACTTCCTTATCTTTTTTTGAATATAATTCAATTATAMGC

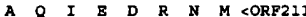

ATATITTTAGCTGTGAAAATGGTAAAATTGTATTAGAAGATTAATAATGAAATGATTTTTTATATCTATAGA ATTC

aldehyde-3-phosphate dehydrogenase. The nucleotide sequence predicted a chain length of 337 amino acid residues and a subunit molecular mass of $36043 \mathrm{Da}$ for $L$. lactis glyceraldehyde-3-phosphate dehydrogenase. A putative ribosome-binding site (GGAGG) was identified 8 bp upstream from the gap initiation codon (Fig. 2).

The $5^{\prime}$ flanking DNA of gap contained two converging ORFs (Fig. 1b) of 137 (Fig. 2; bp 1 to 415) and 161 codons (bp 551 to 1033) that were designated ORF137' and ORF156, respectively. ORF137' extended up to the end of the sequenced DNA and its predicted amino acid sequence shared $53 \%$ identity with the $\mathrm{C}$-terminal residues of ClpL encoded by the plasmid-borne gene $c l p L$ from $L$. lactis (Huang et al., 1993), 42\% identity with the C-terminal residues of ClpA from Bacillus subtilis (Ogasawara et al., 1994), and $34 \%$ identity with the C-terminal residues of the E. coli ClpA (Gottesman et al., 1990a). These findings suggested that ORF137' was the $3^{\prime}$ end of the chromosomal $L$. lactis clp $A$ homologue. ORF156 had a likely ribosome-binding site (AAGGAG) 9 bp upstream from the first ATG codon in the ORF (Fig. 2). Using this ATG as the translation initiation codon, ORF156 was predicted to encode a $17 \cdot 4 \mathrm{kDa}$ protein which shared $33 \%$ identity with the putative Rrf2 regulatory protein of Desulfovibrio vulgaris (Rossi et al., 1993) and $28 \%$ amino acid sequence identity with the putative $16 \mathrm{kDa}$ protein of E. coli (Wolfe \& Smith, 1988). As yet, the genetic and/or biochemical functions of these hypothetical proteins have not been established. The DNA between the translational stop codons of ORF137' and ORF156 contains an inverted repeat sequence (bp 472 to 510; Fig. 2). Transcripts of this region could form stem and loop structures with calculated free energy values (Tinoco et al., 1973) of $-14.6 \mathrm{kcal} \mathrm{mol}^{-1}\left(-61 \mathrm{~kJ} \mathrm{~mol}^{-1}\right)$, followed by UUUUUU. These features are indicative of a bidirectional rho-independent terminator (d'Aubenton Carafa et al., 1990).

The flanking DNA on the $3^{\prime}$ side of gap contains an ORF of 230 codons (bp 2485 to 3174 ; Fig. 2) oriented in the reverse direction to gap (Fig. 1b). This ORF (designated ORF211) has a putative ribosome-binding site (AAGGA) located 14 bp away from the first ATG codon (Fig. 2). Using this ATG as the translation initiation codon, ORF211 was predicted to encode a $23.8 \mathrm{kDa}$ protein which shared $26 \%$ identity with the putative Fms protein of E. coli (Guillon et al., 1992). The function of Fms has not been determined. The DNA between the stop codons

Fig. 2. Nucleotide sequence of $L$. lactis gap, and its flanking DNA. The deduced amino acid sequences are shown for ORF137' (above), ORF156 (below), gap (above) and ORF211 (below). The underlined $C$ at bp 1212 indicates the start point of transcription for gap determined by primer extension analysis. The likely -35 and -10 hexanucleotides of promoters (van de Guchte et al., 1992) are indicated. Double underlining indicates putative ribosome-binding sites which exhibit complementarity to the sequence $3^{\prime}$-UCUUUCCUCCA-5' at the $3^{\prime}$ end of the $L$. lactis 16S rRNA (Ludwig et al., 1985). Asterisks indicate stop codons. The arrows indicate an inverted repeat sequence that is a likely bi-directional rho-independent terminator (d'Aubenton Carafa et al., 1990).
\end{abstract}




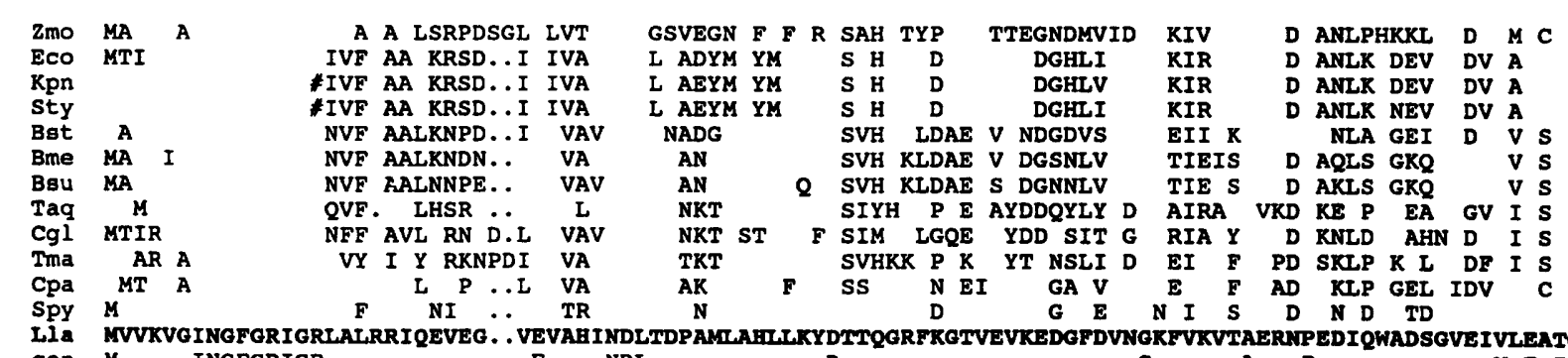

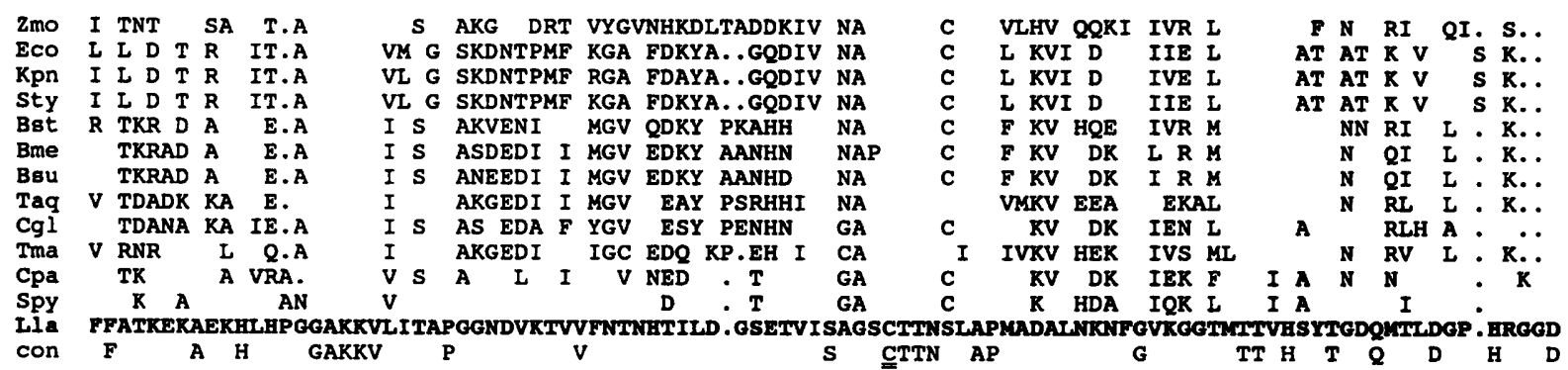

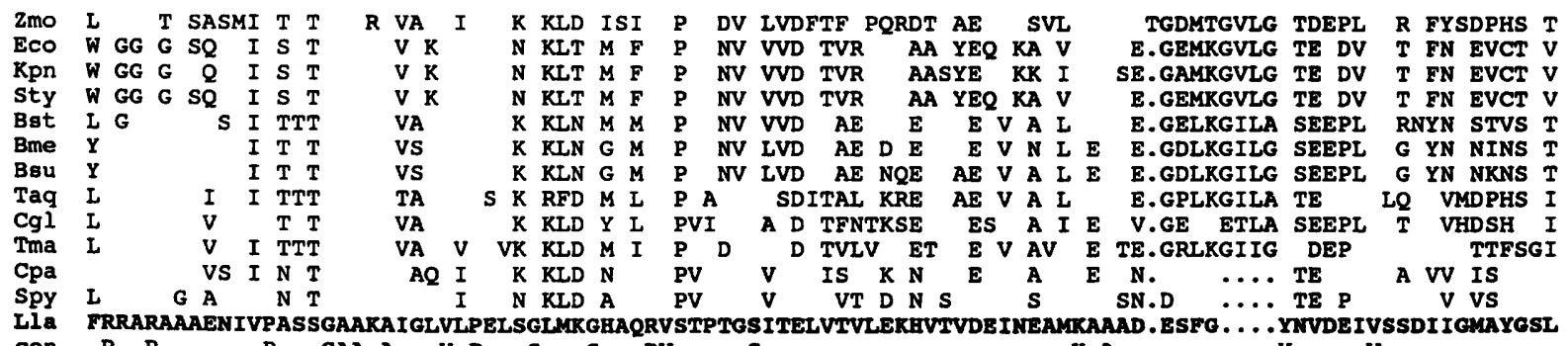

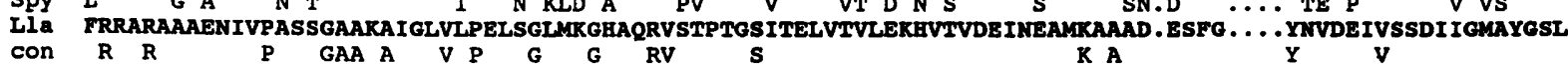

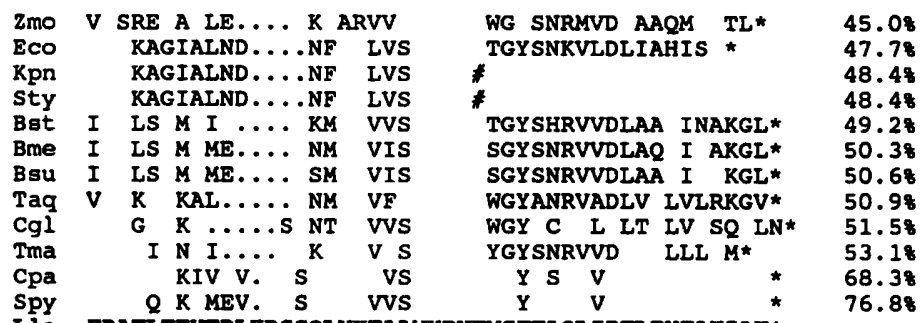

Fig. 3. Homology among the known and deduced amino acid sequences of glyceraldehyde-3-phosphate dehydrogenases from L. lactis and other bacteria, and the PIr protein of Streptococcus pyogenes. The amino acid sequences are shown of the enzyme from: Zymomonas mobilis (Zmo) (Conway et al., 1987), E. coli (Eco) (Branlant \& Branlant, 1985), Klebsiella pneumoniae (Kpn) (Nelson et al., 1991), Salmonella typhimurium (Sty) (Nelson et al., 1991), Bacillus stearothermophilus (Bst) (Biesecker et al., 1977), B. megaterium (Bme) (Schläpfer \& Zuber, 1992), B. subtilis (Bsu) (Viaene \& Dhaese, 1989), Thermus aquaticus (Taq) (Hocking \& Harris, 1980), Corynebacterium glutamicum (Cgl) (Eikmanns, 1992), Thermatoga maritima (Tma) (Schultes et al., 1990), Clostridium pasteurianum (Cpa) (GenBank accession number X72219), S. pyogenes (Spy) (Lottenberg et al., 1992), L. lactis (Lla) (this study), and the conserved amino acids from the above (con). The first amino acid for each protein is the $\mathrm{NH}_{2}$-terminal amino acid. Spaces indicate positions where sequences are identical to that of $L$. lactis; dots indicate gaps inserted into the sequences to maximize the alignment; \# indicates the extremities of partial sequences; double underlining indicates the conserved active-site cysteine from the crystal structure of the $B$. stearothermophilus enzyme (Biesecker et al., 1977); asterisks show the COOH-terminal extremity of each sequence; the percentages show the amount of identity between each sequence and the $L$. lactis sequence.

of gap and ORF211 (bp 2260 and 2485) did not contain any inverted repeat sequences as observed between ORF137' and ORF156, suggesting that transcription of both gap and ORF211 is terminated by a rho-dependent mechanism (Platt, 1994).
The only other ORF larger than 100 codons within the sequenced DNA was one of 122 codons (bp 2611 to 2976). This ORF is totally embedded in ORF211, in the opposite orientation, and had no significant homology with any proteins in the GenPeptide database. We conclude from 
this sequence analysis that no genes encoding other glycolytic pathway enzymes are adjacent to gap in L. lactis.

\section{Expression of L. lactis gap in E. coli}

To establish that we had indeed cloned and sequenced gap, we looked for the expression of glyceraldehyde-3-phosphate dehydrogenase in E. coli cells harbouring pMU5523 and pMU5524, using E. coli strain DF221, a gap amber mutant (Hillman \& Fraenkal, 1975). E. coli DF221 cells are unable to grow if glucose is the sole carbon source, and as a consequence this strain has been used to clone gap from E. coli, Bacillus stearothermophilus, Zymomonas mobilis and B. megaterium (Branlant et al., 1983; Conway et al., 1987; Schläpfer \& Zuber, 1992) by complementation.

Derivatives of E. coli DF221 containing pJDC9, pMU5521, pMU5522, pMU5523 or pMU5524 (Fig. 1b) were constructed by transformation and the ability of transformants to grow on 56/GLC medium was tested. Transformants containing portions of gap (pMU5521 and pMU5522) or pJDC9 (control) grew on Fraenkal II medium but not on 56/GLC. Transformants containing the entire gene (pMU5523 and pMU5524) grew on Fraenkal II medium and on 56/GLC, indicating complementation of the gap mutation of E. coli DF221. Crude cell extracts from transformants were examined by SDSPAGE (data not shown). An increased intensity of staining in the region where a $36 \mathrm{kDa}$ polypeptide would migrate was observed in extracts of $E$. coli DF221(pMU5523) and E. coli DF221(pMU5524), compared with extracts of E. coli DF221 or E. coli DF221(pJDC9). These complementation and SDS-PAGE data together with the nucleotide sequence information established that the DNA of bp 1247 to 2260 in Fig. 2 corresponds to the $L$. lactis gene gap.

\section{Transcriptional analyses}

Northern analysis of L. lactis LM0230 RNA demonstrated that a gap probe hybridized strongly with a single $1.3 \mathrm{~kb}$ transcript (Fig. 4a). Primer extension from oligonucleotide mrc8B using total RNA as template yielded one cDNA product (Fig. 4b). The mobility of the product was identical to that of the product in the $G$ track, corresponding to bp 1212 in Fig. 2. We concluded from this observation that the $C$ at bp 1212 was the $5^{\prime}$ end of the gap transcript. The opposite orientation of the ORFs flanking gap (Fig. 1b), the location of the $5^{\prime}$ end of the gap transcript, and the experimentally determined size of $1.3 \mathrm{~kb}$ for the gap transcript (Fig. 4a), indicated that $L$. lactis gap is expressed as a monocistronic mRNA. Northern analyses (data not shown) of total $L$. lactis RNA using probes $\mathrm{a}, \mathrm{b}$ and $\mathrm{c}$ (Fig. 1b) indicated that a $2.8 \mathrm{~kb}$ transcript hybridized with the ORF137' probe, a $0.7 \mathrm{~kb}$ transcript hybridized with the ORF156 probe, and transcripts of $0.8 \mathrm{~kb}$ (strong) and $1.5 \mathrm{~kb}$ (weak) hybridized with the ORF211 probe.

\section{Codon usage in L. lactis gap}

Codon usage in $L$. lactis gap exhibits a marked bias towards particular codons and away from others (Table (a)

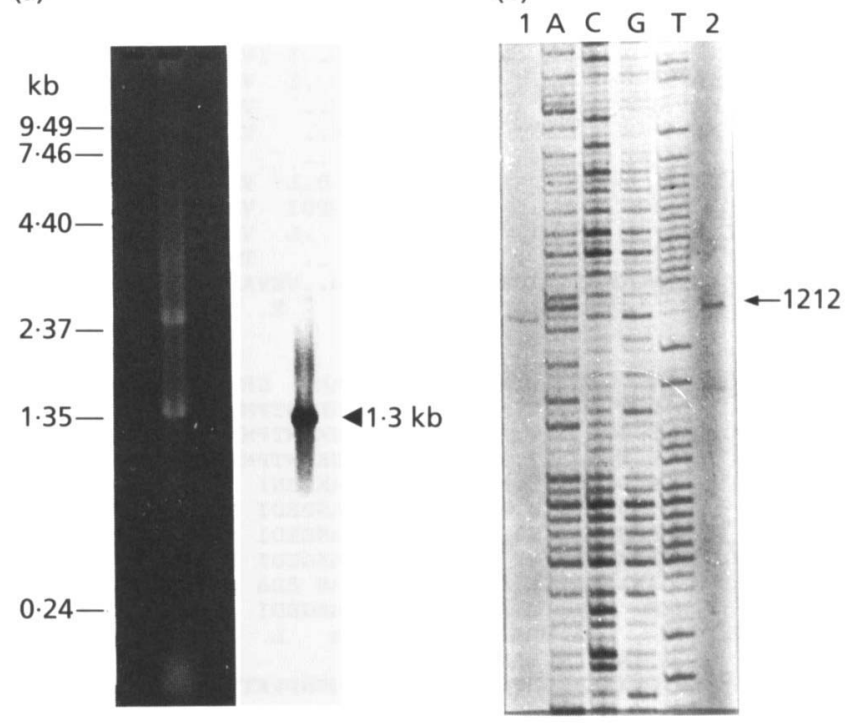

Fig. 4. Transcript analyses of $L$. lactis gap. (a) Northern blot analysis of $L$. lactis LM0230 RNA. Total RNA from L. lactis LM0230 was electrophoresed through a $1.2 \%(\mathrm{w} / \mathrm{v})$ agarose $/ 6 \%$ (v/v) formaldehyde gel and stained with ethidium bromide. RNA was transferred to a nylon membrane, and hybridized with ${ }^{32}$ P-labelled $200 \mathrm{bp}$ gap probe. The numbers on the left indicate the sizes of RNA standards that migrated to the positions indicated. The arrow indicates the $1.3 \mathrm{~kb}$ gap transcript. (b) Primer extension analysis of the $5^{\prime}$ end of gap mRNA. The autoradiograph shows electrophoretic separation of: $10 \%$ of the primer extension reaction (lane 1), and $20 \%$ of the primer extension reaction (lane 2), of CDNA products generated as described previously (Cancilla et al., 1995) using oligonucleotide mrc8B (5'-GTGCGCTACTTCAACTC- $3^{\prime}$ ) as primer. Lanes $A, C, G$ and $T$, electrophoretic separation of the products of dideoxynucleotide sequencing using oligonucleotide mrc8B as primer and plasmid pMU5523 as a template. The number on the right corresponds to the nucleotide sequence numbering in Fig. 2.

2). Of the 61 amino acid codons, 12 are not used in gap. The low $G+C$ content $(37 \mathrm{~mol} \%$ ) of $L$. lactis DNA may explain the non-usage of codons with a $G$ or $C$ in the third position, but it cannot be the reason for the preference for T compared with $A$ in the third position of Leu, Ile, Ala, Arg and Gly codons, or the preference for A compared with $\mathrm{T}$ in the third position of Pro codons.

\section{Chromosomal localization and copy number of gap}

EcoRI, DraI, HaeIII, NruI, SspI, PvuII, HinfI, HindIII, Sau3AI, StuI, HindII and HpaI digests of L. lactis LM0230 chromosomal DNA were resolved by electrophoresis through agarose, and transferred to a nylon membrane. The fragments on the membrane were hybridized with the ${ }^{32}$ P-labelled $3.1 \mathrm{kbp} \mathrm{NruI} \mathrm{fragment} \mathrm{(Fig.} \mathrm{1b),} \mathrm{and} \mathrm{their}$ sizes were determined (data not shown). In all cases, the measured sizes of fragments corresponded with the sizes predicted from restriction mapping (Fig. 1) and sequence data (Fig. 2). These observations indicated the presence of a single copy of gap in the L. lactis LM0230 chromosome. To locate the gene on the physical map of the $L$. lactis DL11 chromosome (Tulloch et al., 1991), samples of high- 


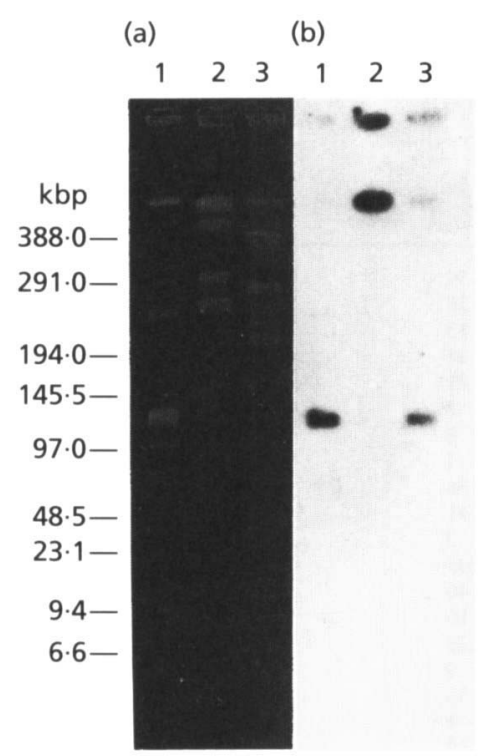

Fig. 5. Southern blot analysis of PFGE separations of restriction digests of high-molecular-mass L. lactis DL11 DNA. (a) DNA was digested in agarose with Smal (lane 1), Notl (lane 2) and SgrAl (lane 3 ) and then subjected to pulsed-field gel electrophoresis through $1.2 \%(\mathrm{w} / \mathrm{V})$ agarose for $20 \mathrm{~h}$ at $200 \mathrm{~V}$. The pulse time was increased linearly from 1 to $30 \mathrm{~s}$. The gel was stained with ethidium bromide. The numbers on the left indicate the sizes (kbp) and migration positions of selected markers from $\lambda$ DNA concatamers (Pharmacia LKB) and markers from a Hindlll digest of $\lambda$ DNA. (b) Southern blot of the gel in (a) after hybridization with ${ }^{32}$-labelled 200 bp gap probe.

molecular-mass DNA from $L$. lactis DL11 were digested with SmaI, NotI and SgrAI, separated by pulsed-field gel electrophoresis, and then transferred to a nylon membrane. The membrane was hybridized with a ${ }^{32} \mathrm{P}$-labelled gap probe (Fig. 5). The probe hybridized with $130 \mathrm{kbp}$ SmaI (lane 1), $750 \mathrm{kbp}$ NotI (lane 2) and $130 \mathrm{kbp} \mathrm{SgrAI}$ (lane 3) fragments. The $750 \mathrm{kbp}$ NotI band corresponded to fragment $\mathrm{NtA}$, while the $130 \mathrm{kbp} \mathrm{SmaI} \mathrm{band} \mathrm{was} \mathrm{SmD}$ as described by Tulloch $e t$ al. (1991). As it has previously been shown that $\mathrm{SmD}$ is located within $\mathrm{NtA}$, we concluded that the single copy of gap is located on the $L$. lactis DL11 chromosome within fragment $\mathrm{SmD}$ between coordinates 0.530 and 0.660 on the physical map (Tulloch et al., 1991).

\section{DISCUSSION}

We have cloned and characterized gap, the gene encoding glyceraldehyde-3-phosphate dehydrogenase from $L$. lactis LM0230. A DNA probe constructed by the PCR was used to isolate a molecular clone containing $g a p$, and to locate a single copy of gap on a physical map of the $L$. lactis chromosome. The identity of the gene was established by the complementation of an E. coligap amber mutant with the L. lactis gap. The deduced amino acid sequence of gap shared significant homology with sequences of glyceraldehyde-3-phosphate dehydrogenase from other bac- teria; the degree of identity ranged from $68 \%$ with the Clostridium pasteurianum enzyme, to $45 \%$ with the Zymomonas mobilis enzyme. Of particular interest was the observation that the L. lactis glyceraldehyde-3-phosphate dehydrogenase was most closely related ( $77 \%$ identity) to the streptococcal plasmin receptor (Plr). It was reported that Plr had glyceraldehyde-3-phosphate dehydrogenase activity, and it has been suggested that Plr is a member of the glyceraldehyde-3-phosphate dehydrogenase family of proteins (Lottenberg et al., 1992).

In some eubacteria gap is clustered with genes encoding other enzymes of the glycolytic pathway. For example, in Corynebacterium glutamicum and Bacillus megaterium a gene cluster of $g a p$, pgk and tpi has been discovered (Eikmanns, 1992; Schläpfer \& Zuber 1992). Transcriptional analyses of the gap-pgk-tpi cluster from C. glutamicum identified transcripts corresponding to gap and gap-pgk-tpi (Schwinde et al., 1993). In Z. mobilis, gap is in a bicistronic operon with $p g k$, and transcripts corresponding to gap and gap-pgk were characterized (Eddy $e t$ al., 1991). In contrast, the active gap $(g a p A)$ of $E$. coli is not clustered with other genes encoding glycolytic pathway enzymes (Branlant \& Branlant, 1985). Studies in E. coli have shown that gap $A$, $p g k$ and $t p i$ are located at 39,63 and 89 min, respectively, on the genetic map (Bachmann, 1990), and that pgk is clustered with fda (encoding fructose, 1,6-bisphosphate aldolase, EC 4.1.2.13) and a second, cryptic gap (gapB) (Alefounder \& Perham, 1989). The flanking DNA of gap from $L$. lactis did not encode other glycolytic pathway enzymes (Fig. 2). We have made a similar observation for the DNA adjacent to tpi in L. lactis (Cancilla $e t$ al., 1995). Transcript analyses indicated that $L$. lactis gap is expressed as a $1.3 \mathrm{~kb}$ monocistronic mRNA. Previous studies demonstrated that $L$. lactis tpi is also monocistronic (Cancilla et al., 1995). The two genes, gap and tpi, are located at least $1.148 \mathrm{Mbp}$ apart on the physical map of the L. lactis DL11 chromosome (Tulloch et al., 1991). These findings show that considerable diversity exists among bacteria with respect to the transcriptional organization of their glycolytic pathway genes.

ClpA is an ATP-dependent protease found in both prokaryotes and eukaryotes (Gottesman et al., 1990b). The Clp family of proteins, ranging in length from 756 to 926 amino acids, are also assumed to function as molecular chaperones (Squires \& Squires, 1992). Recently, clpL from a transposon-like structure on the lactose-protease plasmid of L. lactis CNRZ270 was characterized (Huang et al., 1993). On the basis of sequence identity with the Cterminal residues of ClpL (Huang et al., 1993), and other bacterial ClpA sequences (Ogasawara et al., 1994; Gottesman et al., 1990a), ORF137' is most likely the $3^{\prime}$ end of the chromosomal $L$. lactis clp $A$ homologue. Northern analysis revealed that this gene was expressed on a $2.8 \mathrm{~kb}$ transcript in L. lactis LM0230. Further genetic and biochemical studies are required to establish conclusively the identity of ORF137'.

Based on the different degrees of codon bias in 782 coding sequences, it was postulated that three classes (I, II and 
Table 2. Codon usage in L. lactis

\begin{tabular}{|c|c|c|c|c|c|c|c|}
\hline \multirow[t]{3}{*}{$\begin{array}{l}\text { Amino } \\
\text { acid }\end{array}$} & \multirow[t]{3}{*}{ Codon } & \multirow{2}{*}{\multicolumn{2}{|c|}{$\begin{array}{c}84 \\
\text { chromosomal } \\
\text { genes } \dagger\end{array}$}} & \multicolumn{2}{|c|}{$\begin{array}{l}\text { gap, tpi and } \\
\text { las operon } \neq\end{array}$} & \multicolumn{2}{|c|}{$\begin{array}{c}\text { lac } \\
\text { operon } \S\end{array}$} \\
\hline & & & & \multirow{2}{*}{ Sum } & \multirow[t]{2}{*}{$\%$} & \multirow{2}{*}{ Sum } & \multirow[t]{2}{*}{$\%$} \\
\hline & & Sum & $\%$ & & & & \\
\hline $\mathrm{F}$ & TTT & 1053 & 74 & 32 & 48 & 52 & 50 \\
\hline $\mathrm{F}$ & TTC & 363 & 26 & 34 & 52 & 53 & 50 \\
\hline $\mathrm{L}$ & T'TA & 878 & 30 & 9 & 7 & 24 & 13 \\
\hline $\mathrm{L}$ & TTG & 646 & 22 & 45 & 36 & 56 & 31 \\
\hline $\mathrm{L}$ & CT'T & 812 & 28 & 63 & 50 & 73 & 41 \\
\hline $\mathrm{L}$ & CTC & 241 & 8 & 9 & 7 & 10 & 6 \\
\hline $\mathrm{L}$ & CTA & 195 & 7 & 0 & 0 & 14 & 8 \\
\hline $\mathrm{L}$ & CTG & 145 & 5 & 0 & 0 & 1 & 1 \\
\hline I & ATT & 1595 & 68 & 55 & 45 & 75 & 56 \\
\hline I & ATC & 509 & 22 & 68 & 55 & 54 & 41 \\
\hline I & ATA & 246 & 10 & 0 & 0 & 4 & 3 \\
\hline M & ATG & 726 & 100 & 42 & 100 & 50 & 100 \\
\hline V & GT'T & 1043 & 50 & 97 & 63 & 81 & 46 \\
\hline V & GTC & 364 & 18 & 15 & 10 & 29 & 16 \\
\hline V & GTA & 424 & 21 & 35 & 23 & 50 & 28 \\
\hline V & GTG & 235 & 11 & 6 & 4 & 16 & 9 \\
\hline $\mathrm{S}$ & TCT & 528 & 26 & 24 & 26 & 27 & 35 \\
\hline $\mathrm{S}$ & $\mathrm{TCC}$ & 95 & 5 & 0 & 0 & 1 & 1 \\
\hline $\mathrm{S}$ & $\mathrm{TCA}$ & 668 & 33 & 52 & 56 & 46 & 59 \\
\hline $\mathrm{S}$ & TCG & 102 & 5 & 1 & 1 & 4 & 5 \\
\hline$P$ & ССТ & 382 & 37 & 18 & 34 & 27 & 36 \\
\hline $\mathrm{P}$ & $\mathrm{CCC}$ & 80 & 8 & 0 & 0 & 1 & 1 \\
\hline$P$ & $\mathrm{CCA}$ & 507 & 49 & 33 & 62 & 40 & 53 \\
\hline $\mathrm{P}$ & $\mathrm{CCG}$ & 75 & 7 & 2 & 4 & 8 & 11 \\
\hline $\mathrm{T}$ & $\mathrm{ACT}$ & 645 & 38 & 64 & 60 & 40 & 36 \\
\hline $\mathrm{T}$ & ACA & 665 & 39 & 40 & 37 & 52 & 46 \\
\hline $\mathrm{T}$ & ACG & 188 & 11 & 2 & 2 & 11 & 10 \\
\hline A & GCT & 964 & 41 & 113 & 58 & 88 & 46 \\
\hline A & GCC & 338 & 14 & 12 & 6 & 21 & 11 \\
\hline A & GCA & 826 & 35 & 61 & 31 & 69 & 36 \\
\hline A & GCG & 208 & 9 & 10 & 5 & 13 & 7 \\
\hline $\mathrm{Y}$ & TAT & 811 & 74 & 9 & 24 & 57 & 66 \\
\hline $\mathrm{Y}$ & TAC & 287 & 26 & 29 & 76 & 30 & 34 \\
\hline$*$ & TAA & 60 & 72 & 5 & 100 & 6 & 86 \\
\hline$*$ & TAG & 8 & 10 & 0 & 0 & 1 & 14 \\
\hline $\mathrm{H}$ & CAT & 393 & 73 & 13 & 41 & 24 & 52 \\
\hline $\mathrm{H}$ & CAC & 148 & 27 & 19 & 59 & 22 & 48 \\
\hline Q & CAA & 1068 & 86 & 40 & 100 & 42 & 84 \\
\hline $\mathrm{Q}$ & CAG & 177 & 14 & 0 & 0 & 8 & 16 \\
\hline $\mathrm{N}$ & AAT & 1242 & 77 & 32 & 40 & 55 & 58 \\
\hline $\mathrm{N}$ & AAC & 369 & 23 & 48 & 60 & 40 & 42 \\
\hline $\mathrm{K}$ & AAA & 1964 & 84 & 104 & 96 & 114 & 78 \\
\hline $\mathrm{K}$ & AAG & 384 & 16 & 4 & 4 & 32 & 22 \\
\hline $\mathrm{D}$ & GAT & 1347 & 75 & 59 & 59 & 92 & 71 \\
\hline D & GAC & 461 & 25 & 41 & 41 & 37 & 29 \\
\hline $\mathrm{E}$ & GAA & 1910 & 85 & 133 & 96 & 129 & 83 \\
\hline $\mathrm{E}$ & GAG & 333 & 15 & 5 & 4 & 26 & 17 \\
\hline C & TGT & 123 & 84 & 6 & 100 & 13 & 87 \\
\hline C & TGC & 23 & 16 & 0 & 0 & 2 & 13 \\
\hline$*$ & TGA & 15 & 18 & 0 & 0 & 0 & 0 \\
\hline W & TGG & 269 & 100 & 10 & 100 & 22 & 100 \\
\hline $\mathrm{R}$ & CGT & 436 & 40 & 63 & 89 & 32 & 58 \\
\hline $\mathrm{R}$ & CGC & 100 & 9 & 7 & 10 & 9 & 16 \\
\hline $\mathrm{R}$ & CGA & 156 & 14 & 1 & 1 & 7 & 13 \\
\hline $\mathbf{R}$ & CGG & 65 & 6 & 0 & 0 & 0 & 0 \\
\hline $\mathrm{S}$ & AGT & 457 & 23 & 6 & 6 & 17 & 17 \\
\hline $\mathrm{S}$ & $\mathrm{AGC}$ & 165 & 8 & 10 & 11 & 6 & 6 \\
\hline $\mathrm{R}$ & AGA & 282 & 26 & 0 & 0 & 6 & 11 \\
\hline $\mathrm{R}$ & $\mathrm{AGG}$ & 51 & 5 & 0 & 0 & 1 & 2 \\
\hline G & GGT & 841 & 39 & 106 & 61 & 98 & 59 \\
\hline $\mathrm{G}$ & GGC & 266 & 12 & 13 & 7 & 14 & 8 \\
\hline G & GGA & 839 & 39 & 49 & 28 & 46 & 28 \\
\hline$G$ & GGG & 218 & 10 & 6 & 3 & 9 & 5 \\
\hline \multirow{2}{*}{\multicolumn{2}{|c|}{$\begin{array}{l}\text { Total codons: } \\
\text { Amino acids: }\end{array}$}} & 31221 & & 1761 & & 2096 & \\
\hline & & 31138 & & 1756 & & 2089 & \\
\hline
\end{tabular}

* Stop codon.

† On the basis of the nucleotide sequences for $84 \mathrm{~L}$. lactis chromosomal genes from the following GenBank accession numbers: M35374; X59250; M35865; M58315; M90760; M90761; M87483; L07920; L18760; M65867; M87840; M86245; U05215; M99413; L20851; L14679; M88106; X71132; M33770; D10168; M64860; Z29065; X74298; X75428; X76642; X62621; X71897; L27596; X69123; M87289; L12227; U04468; X52273; L27649; M65089; L11061 and ORF137', ORF156 and ORF211 (this study); ORF318, ORF365 and ORF507 (R. Llanos, Russell Grimwade School of Biochemistry, unpublished data).

$\ddagger$ On the basis of the nucleotide sequences of gap (this study), tpi (Cancilla et al., 1995) and the las operon (Llanos et al., 1993).

@ On the basis of the nucleotide sequences of lac ABCDFEG (de Vos et al., 1990; van Rooijen et al., 1991). 
III) of genes exist in E. coli (Médigue et al., 1991). Nine of the eleven $E$. coli genes encoding glycolytic enzymes, including pgi (encoding phosphoglucose isomerase, EC 5.3.1.9), pfk $A$ (encoding the major phosphofructokinase), tpi and $g a p A$, belong to class II because they show a strong bias in their use of synonymous codons (Médigue et al., 1991). Class II genes are expressed at high levels. Codon usage in $L$. lactis gap exhibits a marked bias towards particular codons and away from others. When these data are combined with codon usage data from $L$. lactis tpi and $p f k$, pyk and ldh (of the las operon), and compared with the codon usage in 84 lactococcal chromosomal genes, a strong bias in the codon usage of glycolytic genes in L. lactis is apparent (Table 2). The extent of this bias is much greater than that in any of the so-called eccentric genes noted in a previous compilation of $74 \mathrm{~L}$. lactis genes, with the exception of the short, 16 codon gene leuL (Chopin, 1993). The plasmid-borne genes of the lac operon (involved in the utilization of lactose) did not exhibit the same degree of bias as that observed in the glycolytic genes (Table 2). In E. coli and Saccharomyces cerevisiae, highly biased codon usage is a property shared by strongly expressed genes (Gouy \& Gautier, 1982; Sharp et al., 1986). We therefore propose that tpi, gap, pfk, $p y k$ and $l d b$ are strongly expressed in L. lactis, in common with glycolytic genes in $E$. coli. The codon preferences in these L. lactis genes (Table 2) most likely reflect a bias in tRNA abundance (Kurland, 1991). Information regarding the optimal codon usage in L. lactis may be useful for identification of coding regions and prediction of gene expression (Gribskov et al., 1984), and in the design of synthetic oligonucleotide primers for PCR amplification of L. lactis genes.

\section{ACKNOWLEDGEMENTS}

We wish to thank Phillip Arnold for synthesis of oligonucleotides and Sean Moore for assistance with gel preparation and use of the automated DNA sequencer. This study was supported by the Australian Research Council and the Australian Dairy Research and Development Corporation. M.R.C. acknowledges receipt of an Australian Dairy Research and Development Corporation Postgraduate Studentship.

\section{REFERENCES}

Alefounder, P. R. \& Perham, R. N. (1989). Identification, molecular cloning and sequence analysis of a gene cluster encoding the class II fructose 1,6-bisphosphate aldolase, 3-phosphoglycerate kinase and a putative second glyceraldehyde-3-phosphate dehydrogenase of Eschericbia coli. Mol Microbiol 3, 723-732.

d'Aubenton Carafa, Y., Brody, E. \& Thermes, C. (1990). Prediction of rho-independent Escherichia coli transcription terminators. A statistical analysis of their RNA stem-loop structures. J Mol Biol 216, 835-858.

Bachmann, B. J. (1990). Linkage map of Eschericbia coli K-12, edition 8. Microbiol Rev 54, 130-197.

Biesecker, G., Harris, J. I., Thierry, J. C., Walker, J. E. \& Wonacott, A. J. (1977). Sequence and structure of D-glyceraldehyde 3phosphate dehydrogenase from Bacillus stearothermophilus. Nature 266, 328-333.
Branlant, G. \& Branlant, C. (1985). Nucleotide sequence of the Escherichia coli gap gene. Different evolutionary behaviour of the $\mathrm{NAD}^{+}$-binding domain and of the catalytic domain of D-glyceraldehyde-3-phosphate dehydrogenase. Eur J Biochem 150, 61-66.

Branlant, G., Flesch, G. \& Branlant, C. (1983). Molecular cloning of the glyceraldehyde-3-phosphate dehydrogenase genes of Bacillus stearothermophilus and Escherichia coli, and their expression in Escherichia coli. Gene 25, 1-7.

Cancilla, M. R., Davidson, B. E., Hillier, A. J., Nguyen, N. Y. \& Thompson, J. (1995). The Lactococccus lactis triosephosphate isomerase gene, $t p i$, is monocistronic. Microbiology 141, 229-238.

Chen, J.-D. \& Morrison, D. A. (1988). Construction and properties of a new insertion vector, pJDC9, that is protected by transcriptional terminators and useful for cloning of DNA from Streptococcus pneumoniae. Gene 64, 155-164.

Chopin, A. (1993). Organization and regulation of genes for amino acid biosynthesis in lactic acid bacteria. FEMS Microbiol Rev 12, 21-38.

Conway, T., Sewell, G. W. \& Ingram, L. O. (1987). Glyceraldehyde3-phosphate dehydrogenase gene from Zymomonas mobilis: cloning, sequencing, and identification of promoter region. $J$ Bacteriol 169, 5653-5662.

Davidson, B. E., Sajgo, M., Noller, H. F. \& Harris, J. I. (1967). Amino-acid sequence of glyceraldehyde 3-phosphate dehydrogenase from lobster muscle. Nature 216, 1181-1185.

Eddy, C. K., Keshav, K. F., An, H., Utt, E. A., Mejia, J. P. \& Ingram, L. O. (1991). Segmental message stabilization as a mechanism for differential expression from the Zymomonas mobilis gap operon. $J$ Bacteriol 173, 245-254.

Efstathiou, J. D. \& McKay, L. L. (1977). Inorganic salts resistance associated with a lactose-fermenting plasmid in Streptococcus lactis. $J$ Bacteriol 130, 257-265.

Eikmanns, B. J. (1992). Identification, sequence analysis, and expression of a Corynebacterium glutamicum gene cluster encoding three glycolytic enzymes, glyceraldehyde-3-phosphate dehydrogenase, 3-phosphoglycerate kinase, and triosephosphate isomerase. J Bacteriol 174, 6076-6086.

Fothergill-Gilmore, L. A. \& Michels, P. A. M. (1993). Evolution of glycolysis. Prog Biopbys Mol Biol 59, 105-235.

Gottesman, S., Clark, W. P. \& Maurizi, M. R. (1990a). The ATPdependent Clp protease of Escherichia coli. Sequence of $c l p A$ and identification of a Clp-specific substrate. J Biol Chem 265, 7886-7893.

Gottesman, S., Squires, C., Pichersky, E., Carrington, M., Hobbs, M., Mattick, J. S., Dalrymple, B., Kuramitsu, H., Shiroza, T., Foster, T., Clark, W. P., Ross, B., Squires, C. L. \& Maurizi, M. R. (1990b). Conservation of the regulatory subunit for the Clp ATP-dependent protease in prokaryotes and eukaryotes. Proc Natl Acad Sci USA 87, 3513-3517.

Gouy, M. \& Gautier, C. (1982). Codon usage in bacteria : correlation with gene expressivity. Nucleic Acids Res 10, 7055-7074.

Gribskov, M., Devereux, J. \& Burgess, R. R. (1984). The codon preference plot: graphic analysis of protein coding sequences and prediction of gene expression. Nucleic Acids Res 12, 539-549.

Griffin, H. G., Swindell, S. R. \& Gasson, M. J. (1992). Cloning and sequence analysis of the gene encoding L-lactate dehydrogenase from Lactococcus lactis: evolutionary relationships between 21 different LDH enzymes. Gene 122, 193-197.

Guillon, J.-M., Mechulam, Y., Schmitter, J.-M., Blanquet, S. \& Fayat, G. (1992). Disruption of the gene for Met-tRNA Met formyltransferase severely impairs growth of Escherichia coli. $J$ Bacteriol 174, 4294-4301. 
van de Guchte, M., Kok, J. \& Venema, G. (1992). Gene expression in Lactococcus lactis. FEMS Microbiol Rev 88, 73-92.

Harris, J. I. \& Waters, M. (1976). Glyceraldehyde-3-phosphate dehydrogenase. In The Enzymes, vol. 13, pp. 1-49. Edited by P. D. Boyer. New York: Academic Press.

Hillman, J. D. \& Fraenkal, D. G. (1975). Glyceraldehyde-3-phosphate dehydrogenase mutants of Escherichia coli. J Bacteriol 122, 1175-1179.

Hocking, J. D. \& Harris, J. I. (1980). D-Glyceraldehyde-3-phosphate dehydrogenase. Amino acid sequence of the enzyme from the extreme thermophile Thermus aquaticus. Eur J Biochem 108, 576-579.

Huang, D. C., Huang, X. F., Novel, G. \& Novel, M. (1993). Two genes present on a transposon-like structure in Lactococcus lactis are involved in a Clp-family proteolytic activity. Mol Microbiol 7, 957-965

Kurland, C. G. (1991). Codon bias and gene expression. FEBS Letters 285, 165-169.

Llanos, R. M., Hillier, A. J. \& Davidson, B. E. (1992). Cloning, nucleotide sequence, expression, and chromosomal location of $l d h$, the gene encoding $\mathrm{L}-(+)$-lactate dehydrogenase from Lactococcus lactis. J Bacteriol 174, 6956-6964.

Llanos, R. M., Harris, C. J., Hillier, A. J. \& Davidson, B. E. (1993). Identification of a novel operon in Lactococcus lactis encoding three enzymes for lactic acid synthesis: phosphofructokinase, pyruvate kinase, and lactate dehydrogenase. J Bacteriol 175, 2541-2551.

London, J. \& Chace, N. M. (1983). Relationships among lactic acid bacteria demonstrated with glyceraldehyde-3-phosphate dehydrogenase as an evolutionary probe. Int J Syst Bacteriol 33, 723-737.

Lottenberg, R., Broder, C. C., Boyle, M. D. P., Kain, S. J., Schroeder, B. L. \& Curtis, R., III (1992). Cloning, sequence analysis, and expression in Escherichia coli of a streptococcal plasmin receptor. $J$ Bacteriol 174, 5204-5210.

Ludwig, W., Seewaldt, E., Kilpper-Bälz, R., Schleifer, K. H., Magrum, L., Woese, C. R., Fox, G. E. \& Stackebrandt, E. (1985). The phylogenetic position of Streptococcus and Enterococcus. J Gen Microbiol 131, 543-551.

Médigue, C., Rouxel, T., Vigier, P., Hénaut, A. \& Danchin, A. (1991). Evidence for horizontal gene transfer in Eschericbia coli speciation. J Mol Biol 222, 851-856.

Monod, J., Cohen-Bazire, G. \& Cohn, M. (1951). Sur la biosynthèse de la $\beta$-galactosidase (lactase) chez Escherichia coli. La specificité de l'induction. Biochim Biopbys Acta 7, 585-599.

Nelson, K., Whittam, T. S. \& Selander, R. K. (1991). Nucleotide polymorphism and evolution in the glyceraldehyde-3-phosphate dehydrogenase gene ( $g a p A$ ) in natural populations of Salmonella and Escherichia coli. Proc Natl Acad Sci USA 88, 6667-6671.

Ogasawara, N., Nakai, S. \& Yoshikawa, H. (1994). Systematic sequencing of the 180 kilobase region of the Bacillus subtilis chromosome containing the replication origin. DNA Res 1, 1-14.

Platt, T. (1994). Rho and RNA: models for recognition and response. Mol Microbiol 11, 983-990.

Poolman, B., Bosman, B., Kiers, J. \& Konings, W. N. (1987). Control of glycolysis by glyceraldehyde-3-phosphate dehydrogenase in Streptococcus cremoris and Streptococcus lactis. J Bacteriol 169, $5887-5890$ van Rooijen, R. J., van Schalkwijk, S. \& de Vos, W. M. (1991). Molecular cloning, characterization, and nucleotide sequence of the tagatose 6-phosphate pathway gene cluster of the lactose operon of Lactococcus lactis. J Biol Chem 266, 7176-7181.

Rossi, M., Pollock, W. B. R., Reij, M. W., Keon, R. G., Fu, R. \& Voordouw, G. (1993). The bmc operon of Desulfovibrio vulgaricus subsp. vulgaricus Hildenborough encodes a potential transmembrane redox protein complex. J Bacteriol 175, 4699-4711.

Salama, M., Sandine, W. \& Giovannoni, S. (1991). Development and application of oligonucleotide probes for identification of Lactococcus lactis subsp. cremoris. Appl Environ Microbiol 57, 13131318.

Schläpfer, B. S. \& Zuber, H. (1992). Cloning and sequencing of the genes encoding glyceraldehyde-3-phosphate dehydrogenase, phosphoglycerate kinase and triosephosphate isomerase (gap operon) from mesophilic Bacillus megaterium: comparison with corresponding sequences from the thermophile Bacillus stearothermopbilus. Gene $122,53-62$.

Schultes, V., Deutzmann, R. \& Jaenicke, R. (1990). Complete amino-acid sequence of glyceraldehyde-3-phosphate dehydrogenase from the hyperthermophilic eubacterium Thermatoga maritima. Eur J Biocbem 192, 25-31.

Schwinde, J. W., Thum-Schmitz, N., Eikmanns, B. J. \& Sahm, H. (1993). Transcriptional analysis of the $g a p-p g k-t p i-p p c$ gene cluster of Corynebacterium glutamicum. J Bacteriol 175, 3905-3908.

Sharp, P. M., Tuohy, T. M. F. \& Mosurski, K. R. (1986). Codon usage in yeast: cluster analysis clearly differentiates highly and lowly expressed genes. Nucleic Acids Res 14, 5125-5143.

Squires, C. \& Squires, C. L. (1992). The Clp proteins: proteolysis regulators or molecular chaperones. J Bacteriol 174, 1081-1085.

Thompson, J. (1987). Regulation of sugar transport and metabolism in lactis acid bacteria. FEMS Microbiol Rev 46, 221-231.

Tinoco, I., Jr, Borer, P. N., Dengler, B., Levine, M. D., Uhlenbech, O. C., Crothers, D. M. \& Gralla, J. (1973). Improved estimation of secondary structure in ribonucleic acids. Nature New Biol 246, 40-41.

Tulloch, D. L., Finch, L. R., Hillier, A. J. \& Davidson, B. E. (1991). Physical map of the chromosome of Lactococcus lactis subsp. lactis DL11 and localization of six putative rRNA operons. $J$ Bacteriol 173, 2768-2775.

Viaene, A. \& Dhaese, P. (1989). Sequence of the glyceraldehyde-3phosphate gene from Bacillus subtilis. Nucleic Acids Res 17, 1251.

de Vos, W. M., Boerrigter, I., van Rooyen, R. J., Reiche, B. \& Hengstenberg, W. (1990). Characterization of the lactose-specific enzymes of the phosphotransferase system in Lactococcus lactis. J Biol Chem 265, 22554-22560.

Wolfe, S. A. \& Smith, J. M. (1988). Nucleotide sequence and analysis of the pur $A$ gene encoding adenylosuccinate synthetase of Escherichia coli K12. J Biol Chem 263, 19147-19153.

Yanisch-Perron, C., Vieira, J. \& Messing, J. (1985). Improved M13 phage cloning vectors and host strains: nucleotide sequences of the M13mp18 and pUC19 vectors. Gene 33, 103-119.

Received 21 October 1994; revised 13 December 1994; accepted 23 December 1994. 